\title{
PENGEMBANGAN MEDIA PEMBELAJARAN PERMAINAN KARTU UNO PADA PEMBELAJARAN MATEMATIKA MATERI SATUAN PANJANG
}

\author{
Tri Azizah Ulfah ${ }^{1)}$, Eva Ari Wahyuni' ${ }^{2)}$, Mohammad Edy Nurtamam ${ }^{3)}$ \\ 1,2,3) Universitas Trunojoyo madura \\ tri.azizahulfah@gmail.com
}

\begin{abstract}
Abstrak
Media pembelajaran merupakan salah satu faktor penting dalam keberhasilan proses pembelajaran. Penggunaan media pembelajaran pada materi satuan panjang sangat penting karena satuan panjang biasanya digunakan dalam menghitung jarak atau panjang suatu benda Tujuan penelitian ini adalah untuk mengetahui kelayakan dan efektifitas media pembelajaran Permainan Kartu Uno dalam pembelajaran matematika materi satuan panjang kelas IV. Dengan media pembelajaran tujuan pembelajaran dapat tersampaikan dengan lebih baik. Penelitian ini menggunakan model 4D yang terdiri dari 4 tahapan define, design, development dan dessiminate. Instrumen dan media penelitian ini telah divalidasi oleh beberapa ahli yaitu ahli bahasa, ahli materi dan ahli media. Terdapat 3 uji coba penelitian yaitu uji coba perorangan, uji coba kelompok kecil, dan uji coba kelompok besar. Berdasarkan hasil penelitian yang dilakukan, diperoleh hasil bahwa persentase kelayakan media pembelajaran Permainan Kartu Uno menurut ahli bahasa adalah 83,33\% (layak), ahli materi $95,23 \%$ (sangat layak), dan ahli media 87,50\% (sangat layak). Efektivitas media pembelajaran Permainan Kartu Uno diukur dari segi proses yaitu pada uji perorangan 93,05\% (sangat efektif), uji kelompok kecil 95,36\% (sangat efektif), dan uji kelompok besar 95,36\% (sangat efektif). Kemenarikan media pembelajaran Permainan Kartu Uno diukur menggunakan angket siswa dengan persentase uji perorangan $88,33 \%$ (sangat menarik), kelompok kecil 98,92\% (sangat menarik), dan kelompok besar 98,92\% (sangat menarik).
\end{abstract}

Kata kunci : Media Pembelajaran, Permainan Kartu Uno, Satuan Panjang, Model Pengembangan 4D

\section{PENDAHULUAN}

Pendidikan merupakan salah satu hal yang menjadi sorotan penting di Indonesia. Melalui pendidikan dapat meningkatkan Sumber Daya Manusia (SDM) suatu bangsa. Kualitas SDM tersebut dapat memajukan bangsa Indonesia serta menjadi bangsa yang mampu bersaing di dunia. Seperti yang tercantum dalam peraturan menteri pendidikan nasional (No.22 Th.2006) kurikulum dilaksanakan dengan menggunakan pendekatan multistrategi dan multimedia, sumber belajar dan teknologi yang memadai, dan memanfaatkan lingkungan sekitar sebagai sumber belajar, dengan prinsip alam takambang jadi guru (semua yang terjadi, tergelar dan berkembang di masyarakat dan lingkungan sekitar serta lingkungan alam semesta dijadikan sumber belajar, contoh dan teladan). Terkait hal tersebut, perlu diterapkan penggunaan media pembelajaran yang dapat menunjang kegiatan pembelajaran dan mencapai tujuan pembelajaran.

Media pembelajaran merupakan salah satu faktor pendukung keberhasilan proses pembelajaran. Media pembelajaran menurut Arsyad (2013:10) adalah segala sesuatu yang dapat digunakan untuk menyampaikan pesan atau informasi dalam proses belajar mengajar sehingga dapat merangsang perhatian dan minat siswa dalam belajar. Penggunaan media pembelajaran dalam proses pembelajaran selama ini belum optimal, apalagi di daerah-daerah pedesaan. Kurangnya wawasan mengenai media pembelajaran dan keterbatasan biaya mungkin selama ini yang menjadi hambatan dalam penggunaan media pembelajaran. Namun, masalah tersebut dapat disiasati dengan memanfaatkan benda-benda di lingkungan sekitar untuk dijadikan sebagai media 
Prosiding Seminar Nasional Matematika dan Pembelajarannya. Jurusan Matematika, FMIPA UM. 13 Agustus 2016

pembelajaran. Berdasarkan hasil observasi di SDN Bulutengger banyak guru yang mengajar hanya mengandalkan ceramah saja dan memanfaatkan papan tulis sebagai media penyampaian materi, serta mengharuskan siswa untuk mendengarkan ceramah guru. Hal ini seharusnya sudah tidak dilakukan lagi, karena dengan pembelajaran seperti itu akan mematikan kreatifitas siswa, membuat siswa merasa jenuh sehingga mengakibatkan hasil belajar siswa tidak optimal. Piaget dalam Heruman (2008:2) menyatakan bahwa idealnya, pada proses pembelajaran, guru seharusnya menggunakan media pembelajaran sebagai salah satu penunjang proses pembelajaran. Siswa SD (7-11 tahun) berada pada fase operasional konkrit, fase di mana perkembangan kognitif masih terkait pada obyek yang konkrit, oleh karena itu siswa memerlukan alat bantu (alat peraga) dan media pembelajaran yang dapat memperjelas materi yang disampaikan oleh guru.

Berdasarkan penelitian terdahulu, diketahui bahwa dengan menggunakan media pembelajaran konkrit pada pembelajaran Matematika materi bangun ruang dapat meningkatkan hasil belajar siswa. Hasil belajar siswa pada SDN Kraton Yogyakarta sebelum menggunakan media pembelajaran konkrit adalah 57,69\% dan setelah menggunakan media pembelajaran konkrit pada pembelajaran Matematika materi bangun ruang meningkat menjadi 84,70\% Pada proses pembelajaran siswa lebih tertarik dan lebih mudah memahami materi pembelajaran (Sulistyanto, 2013). Hal ini membuktikan bahwa penggunaan media pembelajaran dalam proses pembelajaran sangat berpengaruh terhadap hasil belajar siswa terutama pada pembelajaran matematika. Adanya permasalahan tersebut, peneliti mengembangkan media pembelajaran yang dapat membantu siswa memahami materi pembelajaran dengan efektif, menyenangkan dan dapat memberikan gambaran konkrit bagaimana menyelesaikan satun panjang melalui permainan, yaitu dengan menggunakan permainan kartu UNO. Permainan kartu UNO ini berguna sebagai media menentukan satuan panjang yang memiliki nilai sama pada materi pelajaran Matematika kelas IV materi satuan panjang. Pengembangan media dalam penelitian ini berjudul, pengembangan media pembelajaran permainan kartu UNO pada pembelajaran matematika kelas IV materi satuan panjang.

\section{METODE}

\section{Jenis Penelitian}

Jenis pendekatan penelitian ini merupakan penelitian dan pengembangan (Research and Development). Penelitian ini mengembangkan media pembelajaran Kartu Permainan uno sebagai media pembelajaran pada pelajaran matematika materi satuan panjang. Penelitian pengembangan ini sesuai dengan model penelitian pengembangan model pembelajaran 4D. Model pembelajaran 4D dipilih karena kelebihan model pengembangan ini adalah merupakan dasar untuk melakukan pengembangan perangkat pembelajaran yang termasuk di dalamnya media pembelajaran dan tahap-tahap pelaksanaan dibagi secara detail dan sistematik.

\section{Prosedur Penelitian dan Pengembangan}

Prosedur penelitian dan pengembangan pada penelitian ini menggunakan model pembelajaran 4D yang dikembangkan oleh Thiagarajan, Semmel and Semmel (1974). Model 4D ini memiliki 4 tahapan utama yaitu : define (pendefinisian), design (perancangan), development (pengembangan), dan disseminate (penyebarluasan).

\section{Define}

Define merupakan tahap pertama dalam model 4D. Pada tahapan ini terdapat lima langkah yang dilakukan. Lima langkah tersebut yaitu :

a. Front End Analysis

Tahapan pertama yaitu melakukan diagnosis yang terkait dengan pembelajaran di SD Negeri Bulutengger. Pada tahap ini dilakukan wawancara kepada guru kelas IV tentang bagaimana pelaksanaan pembelajaran dan media yang digunakan ketika pembelajaran berlangsung. Ketika wawancara telah dilaksanakan diperoleh informasi bahwa penggunaan 
Prosiding Seminar Nasional Matematika dan Pembelajarannya. Jurusan Matematika, FMIPA UM. 13 Agustus 2016

media pembelajaran selama ini belum optimal. Guru menggunakan buku peganggan dalam proses pembelajaran untuk menunjang pengetahuan siswa. Pada tahap ini secara tidak langsung dapat diketahui karakteristik dari siswa kelas IV.

\section{b. Learner Analysis}

Dalam tahap ini peneliti tidak menggunakan RPP dalam mengajar karena penelitian hanya sebatas pengembangan media Kartu Permainan Uno yang diuji kelayakan dan keefektifan dari media tersebut. Wawancara dan observasi di awal dapat diketahui bahwa kelas IV tidak menggunakan media pembelajaran yang menarik hanya menggunakan Buku sebagai peganggan siswa dalam pembelajaran. Hal ini membuat siswa menjadi bosan dengan hanya mengerjakan soal-soal yang ada di buku. Pada pembelajaran ini siswa dituntut untuk aktif dalam belajar melalui permainan Uno pada materi satuan panjang.

c. Task Analysis

Tahap Task Analysis ini merupakan tahapan dimana terdapat analisis mengenai tugastugas pokok yang harus dipahami siswa untuk dapat mencapai kompetensi minimal yang harus dimiliki setelah pembelajaran berlangsung. Tahap ini adalah dilakukannya penyusunan indikator pembelajaran pada pembelajaran matematika materi satuan panjang pada kelas IV. Ada beberapa indikator pembelajaran, tetapi indikator tersebut dapat dikembangkan sesuai dengan kebutuhan dari suatu pembelajaran tersebut.

d. Concept Analysis

Tahap Concept Analysis (Analisis Konsep) merupakan kegiatan menganalisis konsep yang akan diajarkan kepada siswa, sehingga kompetensi minimal siswa dapat tercapai. Menganalisis konsep yang diajarkan, menyusun langkah-langkah yang akan dilakukan adalah kegiatan yang dilaksanakan pada tahap ini. Hasil analisis tersebut maka dapat mengetahui kekurangan media yang dibuat sebelumnya.

e. $\quad$ Specifying Instructional Objectives

Pada tahap ini dilakukan pengidentifikasian tujuan pembelajaran yang akan diperoleh oleh siswa di akhir pembelajaran tentang materi satuan panjang. Tujuan pembelajaran dapat mengukur keberhasilan dari pembelajaran yang dilakukan. Jika tujuan pembelajaran tidak tercapai maka dapat dikatakan pembelajaran yang telah dilakukan tidak berhasil atau gagal.

\section{Design (Perancangan)}

Pada tahap sebelumnya telah ditetapkan materi, indikator pembelajaran, dan tujuan pembelajaran yang akan dilaksanakan dalam proses pembelajaran. Kegiatan awal yang dilakukan dalam tahap design yaitu menetapkan media yang digunakan. Media pembelajaran Permainan Kartu Uno ini harus disesuaikan dengan tujuan dan materi pembelajaran. Kemudian dilakukan penyusunan strategi pembelajaran dan teknik penggunaan media pembelajaran yang sesuai dengan kondisi siswa. Pada tahapan akhir diperoleh desain awal media pembelajaran Permainan Kartu Uno.

\section{Develop (Pengembangan)}

Pada tahap sebelumnya telah diperoleh desain awal media pembelajaran Permainan Kartu Uno. Setelah diperoleh desain awal media selanjutnya dilakukan validasi oleh ahli. Validasi oleh ahli ini akan dilakukan dengan tiga validasi yaitu validasi ahli bahasa, validasi ahli media dan validasi ahli materi. Setelah di validasi oleh ahli dapat diperoleh revisi desain awal yang digunakan untuk menguji coba perorangan dengan jumlah siswa 1-3 orang selanjutnya jika terdapat kekurangan pada media yang diuji cobakan pada uji coba perorangan maka dapat dilakukan revisi produk awal. Selanjutnya dilakukan uji coba kelompok kecil dimana jumlah siswa berkisar antara 6-9 orang. Jika dalam uji coba kelompok terdapat kekurangan maka kembali dilakukan revisi produk. Jika tidak ada revisi maka media Permainan Kartu Uno ini sudah merupakan produk akhir.

\section{Disseminate (Penyebarluasan)}


Prosiding Seminar Nasional Matematika dan Pembelajarannya. Jurusan Matematika, FMIPA UM. 13 Agustus 2016

Menurutn Al-Tabany (2014 : 235) tahap ini merupakan tahap penggunaan media yang telah dibuat dan dikembangakan pada skala yang lebih luas, misalnya di kelas lain, di sekolah lain, oleh guru lain. Tujuan lain yaitu untuk menguji efektifitas penggunaan media di dalam proses kegiatan belajar mengajar. Sehingga peneliti menggunakan sekolah lain dengan tingkatan kelas yang sama untuk tahap desiminasi.

\section{Instrumen Pengumpulan Data}

Arikunto (dalam Riduwan, 2012:24) menjelaskan bahwa instrumen adalah alat bantu atau fasilitas yang digunakan dalam mengumpulkan data secara cermat, lengkap dan sistematis sehingga mudah diolah dengan hasil yang lebih baik. Peneliti menggunakan instrument angket, observasi dan dokumentasi.

\section{HASIL DAN PEMBAHASAN}

Hasil pengembangan penelitian media Permainan Kartu Uno ini menggunakan model 4D terdiri dari 4 tahapan yaitu pendefinisian (define), perancangan (design), pengembangan (development), desiminasi/penyebaran (dessiminate). Hasil pengembangan model 4D media pembelajaran terdiri dari 4 tahapan tersebut akan dijabarkan sebagai berikut:

\section{Pendefinisian (define)}

Media permainan kartu uno ini belum pernah digunakan oleh guru kelas IV sehingga peneliti memilih untuk mengembangkan media permainan kartu uno. Siswa kelas IV SDN Bulutengger dengan rata-rata usia 8-9 tahun. Seperti yang dikemukakan oleh Piaget (dalam Mujtahidin, 2014: 67) perkembangan anak yang terjadi pada usia 7-11 tahun termasuk pada tahap operasional konkret. Tahap ini anak sudah mulai melakukan operasi, mulai dapat berpikir rasional. Oleh karena itu anak pada usia ini masih membutuhkan sebuah pembelajaran yang bersifat konkret dan sesuai dengan lingkungan kehidupan sekitar yang pernah dialaminya. Adanya media permainan kartu uno dapat membantu siswa untuk memahami materi dengan mudah sesuai pengalaman dan lingkungan sekitar siswa yaitu melalui permainan.

\section{Perancangan (design)}

Tahapan design merupakan tahapan peneliti dan pengembang untuk memulai membuat sketsa produk media yang akan dikembangkan dan disajikan di sekolah SDN Bulutengger Lamongan. Setelah rancangan sketsa yang dibuat disetujui oleh dosen pembimbing dengan saransaran yaitu agar media yang dibuat bisa digunakan dalam jangka waktu yang lama, mencetak kartu pada kertas art paper dan didalam kartu terdapat penyelesean satuan panjang.

\section{Pengembangan (development)}

Tahapan selanjutnya yaitu pengembangan desain awal media permainan kartu uno dengan melakukan validasi desain yaitu tanggapan atau hasil validasi ahli bahasa terhadap tata bahasa prosedur penggunaan media permainan kartu uno, tanggapan atau hasil validasi ahli materi terhadap kesesuaian materi yang diajarkan dengan pembelajaran terhadap produk pengembangan media permainan kartu uno, tanggapan atau hasil validasi ahli media pembelajaran terhadap produk pengembangan media permainan kartu uno. Validasi media yang terdiri dari validasi validasi bahasa, validasi materi dan validasi media pada produk permainan kartu uno yang dilakukan oleh para ahli untuk mengetahui kelayakan, keefektifan, serta saran/tanggapan dari media pengembangan yang telah dibuat dan kemudian dilakukan perbaikan jika mendapat saran dari tim ahli validator. Dari hasil analisis data yang terkumpul dapat dijadikan pertimbangan untuk melakukan revisi pada produk pengembangan media permainan kartu uno.

Ahli Hasil validasi Kriteria




\begin{tabular}{|lll|}
\hline Bahasa & $83,33 \%$ & Valid \\
Materi Pembelajaran & $95,23 \%$ & Sangat valid \\
Media Pembelajaran & $87,50 \%$ & Sangat valid \\
\hline
\end{tabular}

Uji coba ini dilakukan setelah tahap validasi dan perbaikan desain telah dilakukan. Uji coba perorangan dilakukan dengan jumlah 3 siswa, uji kelompok kecil dilakukan dengan jumlah 7 siswa dan kelompok besar dilakukan dengan 20 pada kelas IV SDN Bulutengger dengan perbedaan laki-laki dan peremuan dan berbagai kecerdasan. Siswa kelas IV diberikan angket respon yang kemudian diisi oleh masing-masing siswa mengenai tanggapannya terhadap media permainan kartu uno yang disajikan oleh peneliti dan pengembang. Saat pembelajaran berlangsung 3 observer memberikan penilaian terhadap proses guru (peneliti) mengajar dan aktivitas siswa di dalam kelas. Setelah pembelajaran dengan menggunakan media kartu uno selesai, kemudian peneliti dan pengembang merekap lembar observasi dari 3 observer dan hasil respon. Hasil hitungan oleh peneliti akan dijabarkan sebagai berikut:

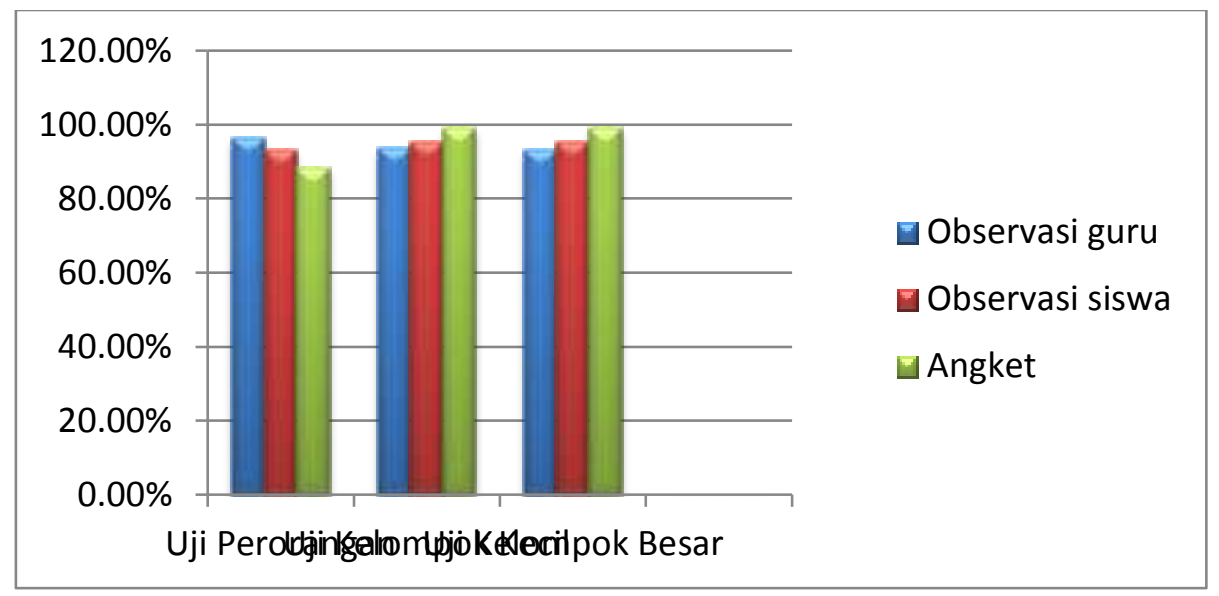

\section{Desiminasi atau Penyebaran}

Tahap terakhir dari 4D yaitu Penyebaran. Setelah melewati beberapa tahapan dalam pengembangan produk maka pada tahap Penyebaran ini media yang telah dibuat oleh peneliti dan pengembang akan di sebarkan ke sekolah lain. Hal ini sejalan dengan Al-Tabany (2014 : 235) tahap ini merupakan tahap penggunaan media yang telah dibuat dan dikembangakan pada skala yang lebih luas, misalnya di kelas lain, di sekolah lain, oleh guru lain. Tujuan lain yaitu untuk menguji efektifitas penggunaan media di dalam proses kegiatan belajar mengajar. Sehingga peneliti menggunakan sekolah lain dengan tingkatan kelas yang sama untuk tahap desiminasi yaitu SD Negeri Delek Sumber Gresik.

\section{Pengembangan Media Permainan Kartu Uno Satuan Panjang}

Media permainan kartu uno ini telah disetujui oleh tim ahli dan responden. Keberadaan media permainan kartu uno dapat membantu guru dan siswa berinteraksi dengan mudah. Siswa dapat lebih mudah memahami materi pelajaran yang sedang dipelajari karena penggunaan media melaui permainan edukatif, hal ini dapat dilihat dari hasil observasi siswa pada saat melaksanakan pembelajaran materi satuan panjang berbantuan media permainan kartu uno. Media permainan kartu uno juga membantu membangkitkan keaktifan siswa di dalam kelas.

\section{Hasil Produk Permainan Kartu Uno Satuan Panjang}

Media permainan kartu uno yang dibuat untuk siswa kelas 4 SD ini memiliki beberapa bagian yang digunakan pada saat proses pembelajaran. Bagian-bagian ini terdiri dari:

\section{a. Kotak kartu}


Prosiding Seminar Nasional Matematika dan Pembelajarannya. Jurusan Matematika, FMIPA UM. 13 Agustus 2016

Kotak kartu ini digunakan agar kartu dapat tersimpan lebih aman dan tahan lama. Alat dan bahan yang digunakan yaitu kaleng bekas, lem dan flanel. Cara membuatnya yaitu:

1) Potong flanel sesuai dengan bentuk dan ukuran kaleng bekas.

2) Untuk menarik perhatian siswa maka peneliti menghias kaleng menyerupai buah strawberry.

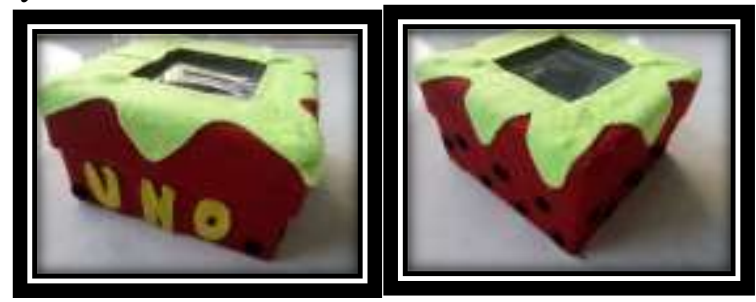

Gambar: kotak kemasan kartu uno

b. Alas permainan

Alas permainan ini digunakan untuk mempermudahkan siswa dalam mengoprasikan media. Alas permainan ini dibuat sedemikian rupa agar dapat digunakan dalam jangka waktu yang panjang maka pengembang membuat dari kertas duplex yang di lapisi plastik. Cara membuatnya yaitu:

1) Potong duplex seperti bangun persegi panjang

2) Setiap sisi buatlah persegi kecil-kecil nantinya untuk tempelan satuan panjang

3) Lapisi dupleks dengan kertas warna emas

4) Hias semenarik mungkin sesuai karakteristik anak SD

5) Terakhir lapisi dengan plastik

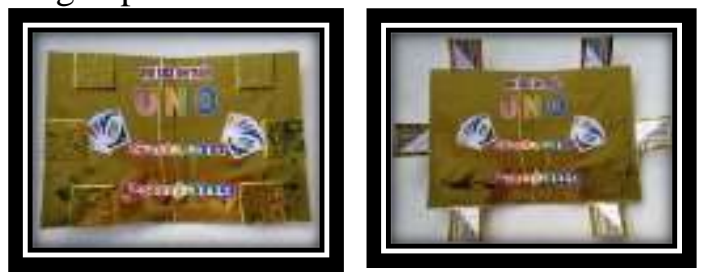

Gambar: Alas kartu uno

\section{KESIMPULAN DAN SARAN}

\section{A. Kesimpulan}

Peneliti menggunakan model pengembangan model Thiagarajan sebagai prosedur penelitian. Penelitian ini termasuk jenis penelitian pengembangan perangkat pembelajaran yaitu media pembelajaran, maka pada tahap pengembangan development peneliti melaksanakan validasi bahasa, validasi materi dan validasi media sedangkan pada tahap uji coba peneliti melaksanakan uji perorangan, uji kelompok kecil dan uji kelompok besar untuk mengetahui kelayakan dan efektivitas media pembelajan kartu uno pada pembelajaran matematika kelas IV materi satuan panjang.

pengembangan ini menghasilkan produk permainan kartu uno sebagai media pembelajaran dengan materi satuan panjang layak digunakan untuk siswa kelas IV SDN Bulutengger Lamongan.

\section{B. Saran}

Permainan kartu uno ini digunakan untuk mengukur pemahaman materi satuan panjang dengan disertai latihan-latihan soal pada proses pembelajaran dengan model pembelajaran 
Prosiding Seminar Nasional Matematika dan Pembelajarannya. Jurusan Matematika, FMIPA UM. 13 Agustus 2016

langsung dan memberikan umpan balik, sehingga guru tetap memberikan penjelasan dan bimbingan kepada siswa tentang materi satuan panjang. Permainan kartu uno sebagai media pembelajaran matematika materi satuan panjang dapat digunakan pada semua jenis metode pembelajaran. Penelitian selanjutnya diharapkan agar produk permainan kartu uno dapat dikembangkan dalam bentuk game online.

\section{DAFTAR PUSTAKA}

Al-Tabany, Trianto. 2014. Mendesain Model Pembelajaran Inovatif, Progresif, dan Kontekstual. Jakarta : Prenadamedia Group.

Arsyad, Azhar. 2013. Media Pembelajaran. Jakarta: Rajawali Pers.

Heruman. 2008. Model Pembelajaran Matematika Di Sekolah Dasar. Bandung: PT Remaja Rosdakarya.

Hidayati, Nurul dan Hakim, Luqman. 2014. Pengembangan Permainan Kartu Uno Sebagai Alat Evaluasi Pembelajaran Akuntansi Pokok Bahasan Hutang Jangka Panjang. Artikel Ilmiah. Universitas Negeri Surabaya.

Mujtahidin. 2014. Teori Belajar dan Pembelajaran. Surabaya: Pena Salsabila.

Musfiqon. 2012. Pengembangan Media \& Sumber Pembelajaran. Jakarta: PT Prestasi Pustakarya.

Riduwan. 2012. Skala Pengukuran Variabel-Variabel Penelitian. Bandung: Alfabeta.

Sadiman, Arief S., Rahardjo., Anung Haryono \& Rahardjito. 2012. Media Pendidikan. Jakarta: PT. Rajagrafindo Persada.

Sulistyanto, Wakit. 2013. Upaya Meningkatkan Hasil Belajar Bangun Ruang Menggunakan Media Konkret Pada Siswa Kelas IV SD Negeri KratonYogyakarta. Skripsi. Universitas Negeri Yogyakarta.

Thiagarajan, S. Semmel, D.S Semmel, M.I. 1974. Instructional Development for Training Teachers of Exceptional Children: A Sourcebook. Blomington : Indiana University. 